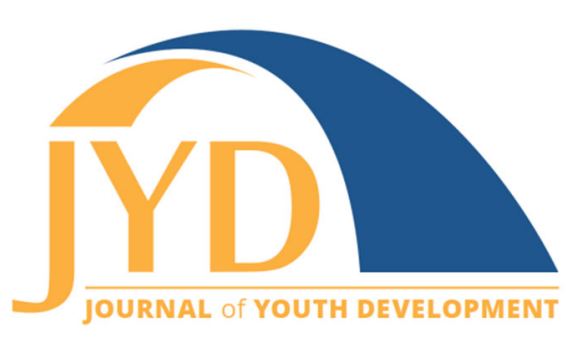

http://jyd.pitt.edu/ | Vol. 15 Issue 5 DOI 10.5195/jyd.2020.869 | ISSN 2325-4017 (online)

\title{
Supporting Interests and Sharing Power: Insights From a Scottish Youth Program
}

\author{
Daniela Kruel DiGiacomo \\ University of Kentucky \\ daniela.digiacomo@uky.edu
}

\begin{abstract}
Light Up Learning (LUL) is a youth program in Scotland that supports young people in pursuing their curiosities and exploring their interests in a school-based informal learning setting. This article draws on interview and participant observation data to examine the social organization of teaching and learning activity within LUL. As a school-based program focused on supporting youth in pursuing their interests through the cultivation of a caring adult-youth relationship, LUL offers an empirical case that brings together insights from youth development and interest-driven learning research. Examination into the verbal and material interactions that shape adult-youth interactions yields insight into how to challenge normatively hierarchical power dynamics between teachers and learners toward the instantiation of a more relational pedagogy. By employing the pedagogic moves of continually foregrounding youths' interests, honoring youth expertise, and making space for youth's ideas, LUL youth workers created an environment within a school setting where youth felt both free and supported to learn through deeply and widely pursuing their interests.
\end{abstract}

Key words: interest-driven learning; adult-youth relations; relational pedagogy; youth development

Research on learning and development has, for decades, demonstrated the importance of learning within "informal" settings that are supportive of the diverse developmental needs of children and youth (Ito et al., 2020; Rogoff, 1990; Sefton-Green, 2012). More recently, scholarship on youth has shown the power of youth organizing spaces (Kirshner, 2015), community-situated youth development programs (Baldridge, 2019), and connected learning sites (Ito et al., 2020) to provide rich opportunities for the type of interest- and relationallydriven learning experiences known to be critical for youth development (Barron, 2006; DiGiacomo \& Penuel, 2018; Nakkula \& Toshalis, 2006). Despite what is known about the benefits of these spaces and programs for youth learning and development, they remain the exception, rather than the expectation, for how school is designed. Inspired by this problem of

(cc) EY New articles in this journal are licensed under a Creative Commons Attribution 4.0 License. This journal is published by the University Library System, University of Pittsburgh and is cosponsored by the University of Pittsburgh Press. The Journal of Youth Development is the official peer-reviewed publication of the National Association of Extension 4-H Youth Development Professionals and the National AfterSchool Association. 


\section{Insights From a Scottish Youth Program}

practice, this study offers an examination of the case of Light Up Learning, a school-based youth program in the working-class suburbs of Edinburgh, Scotland whose mission is to encourage informal learning within school walls and during school hours.

As a school-based program focused on supporting youth in pursuing their interests through the cultivation of a caring adult-youth relationship, Light Up Learning offers an empirical case that brings together insights from youth development and interest-driven learning research. Light Up Learning is focused on supporting young people in a setting outside of academic or curricular constraints, as such it can be understood broadly as a program trying to promote youth development. As a program whose primary activity is to encourage young people to pursue their genuine interests and curiosities, its design principles also reflect tenets of interest-driven and/or interest-related learning and youth-adult partnerships.

\section{Situating the Work of Light Up Learning in Theory and Practice}

Children and young people participate in various forms of learning activity outside of school hours. Long understood as a supportive complement to in-school learning, out-of-school time (OST) or after-school programs (hereafter OST) have played, and continue to play, a significant role in the lives of young people. OST programming has typically been associated with increased emphasis on the whole child, rather than a sole focus on the academic or intellectual development of a young person (Halpern, 2002). Investments in OST, while following the ebb and flow of public sector funding, have continued to proliferate in recent decades, with substantial funds allocated toward after-school initiatives, such as the $21^{\text {st }}$ Century Community Learning Centers in the United States and the amplification of third-sector funding in the United Kingdom (Honig \& McDonald, 2005; Scottish Executive, 2013). While varied in type and scope, there is ample evidence that OST programming continues to play an important role in young people's learning and development (Patall et al., 2010; Rocha, 2006). Of particular relevance to the empirical investigation of Light Up Learning, there remains substantive focus within research on youth learning and development on the importance of adult-youth relationships and interest-driven learning.

\section{Adult-Youth Relationships in Youth Development}

Across research on youth development, the notion that social relationships matter for youth learning is strong (Halpern, 2005; Nakkula \& Toshalis, 2006; Zeldin, 2012). Whether through 


\section{Insights From a Scottish Youth Program}

the discussion of mentoring, youth-adult partnerships, or the design of after-school programs, one would be hard pressed to find research on youth development that does not include some discussion of the mediating role of positive social relationships. For instance, seminal research on youth development argues that best practice requires attention to the physical, intellectual, psychological/emotional, and social development of young people-supported in large part by opportunities to "feel a sense of belonging and valued" (Eccles \& Gootman, 2002, p. 8).

Positive youth development (PYD), or the healthy development of social and personal assets, is a branch of youth development research that has retained popularity since the 1990s (see R. Larson, 2000). PYD has been lauded for its assets-based framing of youth as capable, as well as for its attention to contemporary research about how young people learn. According to Eccles and Gootman (2002) the design features of learning environments that support the diverse and fluid developmental needs of adolescent youth include (a) physical and psychological safety; (b) appropriate structure, including clear, consistent adult guidance; (c) supportive relationships; (d) opportunities to belong; (e) positive social norms; ( $f$ ) support for mattering; (g) opportunities for skill building; and (h) the fluid integration of family, school, and community. Conceptualized as the construction of adolescence (Nakkula \& Toshalis, 2006), positive youth development involves adolescents experimenting with their identities, a process that necessarily indexes their evolving social, relational, and cultural experiences.

PYD contexts are knowledge-centered, youth-centered, and assessment-centered (Brown, 1992; McLaughlin, 2000). In addition, PYD environments, such as those found within community-based organizations, sports, or arts programming are documented to be critical for youth development because they offer the "rare combination of intrinsic motivation in combination with deep attention" (R. Larson, 2000, p. 170), creating the potential for sustained engagement in meaningful learning activity, as well as opportunity to relate to others in such activity. Young people's relationship(s) with others is of central import in discussions of PYD, as reflected by each of the aforementioned emphases on the social aspect of adolescent learning and development.

Even more focused on the importance of social relationships than PYD research, youth-adult partnership (YAP) research argues that the type of relationship between adults and youth during adolescence also matters (see R. Larson, 2000; Zeldin et al., 2013). As youth develop, they are continually asked to make sense of the evolving world around them, including their own place within their changing world. For this reason, the types of social relations and 


\section{Insights From a Scottish Youth Program}

experiences that youth have during this time are especially important for how youth come to see, value, or devalue themselves as participants in the world around them.

According to Zeldin et al. (2013), a youth-adult partnership in a teaching and learning setting ought to be developmental, rather than prescriptive, to encourage shifting power and responsibility, which orients the youth toward a sense of community and shared goals. For Halpern (2005), youth-adult partnerships are most successful if they are also characterized by joint, task-oriented activities like the production of some new media form or the construction of a piece of furniture. Such relations demonstrate the potential to create stronger senses of valued, capable selves for youth who are often unsure about their identities as valued members of a practice, group, or learning setting. A consistent thread in youth development work then, is the need for adults to organize for the healthy development of personal and social assets of young people by themselves serving as "developmental" allies (Kirshner, 2015).

\section{Interest-Driven Learning in Youth Development}

The notion that learning environments should leverage and build upon young people's interests is strong within contemporary research in learning sciences and youth development. Made wellknown in the field by Hidi and Renninger (2006)'s four phase model of "interest development," including triggered situational interest, maintained situational interest, emerging individual interest, and well-developed individual interest, the diversity and texture of young people's interests and their connection to learning experiences and outcomes is well documented (Barron, 2006). The Connected Learning framework, which argues for learning that "connects personal interests, supportive relationships, and academic, civic, and career opportunity" (Ito et al., 2020, p. 4). has long proposed "interest-powered" as one of its central principles. Connected Learning-inspired research, in particular, has done especially well within the last decade to evidence the multiple ways in which learning activity and environment design should foreground youth interest(s) (c.f. K. Larson et al., 2013).

More recently, inquiry on interest has shifted toward the concept of "interest-related"- a notion which reflects an understanding of how social connections, developing identit(ies), and the ability to collaborate and reflect in joint activity organize the means through which a young person develops or maintains interest(s) (Allen et al., 2018; DiGiacomo et al., 2018; Penuel et al., 2016). In practice as well, contemporary designers of interest-driven learning environments have extended research on what is known about the critical relation between youth interest(s) and learning into the design of new media-supported informal learning innovations (Pinkard et 


\section{Insights From a Scottish Youth Program}

al., 2017; Stevens et al., 2016). Over the past 2 decades, in fact, research within OST spaces by informal learning scholars has evidenced the important role interest plays in supporting learning and youth development within these programs, ranging from research on the Fifth Dimension or University of California Links programs (Cole \& The Distributed Literacy Consortium, 2006; Lecusay, 2015) to gaming or affinity spaces (Gee, 2007; Ito et al., 2020).

\section{Theory Into Practice: The Exception, Rather Than the Expectation}

Despite ongoing and compelling research about the critical importance of youth-adult relationships and interests for supporting youth learning and development, these central tenets remain largely the exception, rather than the expectation, for how learning in schools is designed. Simply put, we know little about how to organize for interest-driven learning in school settings in ways that are supportive of youth development. As Walkington and Bernacki (2014) have suggested, there is a need for more empirical work that puts to test learning and youth development designs organized to support youth interests within a range of educational settings. Contemporary youth development and learning design work then faces a significant challenge: how to document and provide evidence of important developmental experiences (such as youth-adult partnerships or interest-driven learning) that remain largely processoriented and difficult to measure (Michalchik \& Gallagher, 2010).

To be sure, youth programs and schools do not exist in a vacuum and operate in constrained contexts that must continuously contend with broader socioeconomic shifts in society (Halpern, 2002). For the past several years, this has meant that demonstrations of learning and youth development are often most valued to the extent that they can produce instrumentally oriented gains, such as better performance on tests or reduced delinquency (Kwon, 2013). Given these challenges, it is perhaps not surprising that despite strong theoretical commitments to the importance of youth-adult relationships and interest-related learning in the fields of learning and youth development, there remains little empirical research on youth programs whose focus is on learning-for-learning's sake-as is the case for the program under investigation. It is within this complex and contradictory landscape that I approached the present investigation, animated broadly by a desire to understand how Light Up Learning supported youth learning and development. 


\section{Insights From a Scottish Youth Program}

\section{Country and Program Context}

In Scotland, in order to go to a university directly after secondary school, students must first choose to stay in school past age 15/16. At this age, which is typically in Year 4 of secondary school, students take a series of exams called the "National 4/5's" (formerly known as "Standard Grades"). Mathematics and English are compulsory, while the remaining four to six exams are the students' choice. Pending exam results, students can choose to leave school altogether, leave and attend college (similar to a community college in the United States), or stay in school for 1 to 2 more years and apply for university (akin to a 4-year university in the United States). If they choose to stay, students then take "Higher" exams (necessary to apply directly to university), followed by "Advanced Higher" exams (credits equivalent to first year of university; can also be taken if Higher results are not desirable). Students' access to both the types and quality of postsecondary opportunities are highly dependent on their performance on the exams.

While emphasis on exam performance persists, it is worthwhile noting that Scotland has recently made a distinct curricular turn toward foregrounding the importance of the 'whole child' through an interdisciplinary, lifelong approach to learning via national adoption and implementation of the Curriculum for Excellence (CfE). The CfE aims to "help children and young people gain the knowledge, skills, and attributes needed for life in the $21^{\text {st }}$ century, including skills for learning, life and work." Similar in part to the Common Core State Standards Initiative in the United States, the CfE emphasizes the importance of inquiry and critical thinking and is guided by seven principles: challenge and enjoyment, breadth, progression, depth, personalization and choice, coherence, and relevance. While the development and adoption of CfE reflects a concerted effort by the Scottish government, at least in name, to make schooling more enjoyable and relevant for young people, young people's experiences learning in school are still largely oriented around and toward their performance on a handful of exams that dictate the type, if any, of postsecondary educational opportunities they will have (Hamilton \& Brown 2005; Watson, 2010).

\section{Program Context}

Light Up Learning (hereafter LUL) is a youth program housed in a large secondary school in the working-class suburbs of Edinburgh, Scotland. LUL aims to provide a space for young people to learn through pursuing their curiosities and exploring their interests, within the school day and within the school's walls. In Scotland, as in many countries in the industrialized world, being 


\section{Insights From a Scottish Youth Program}

able to routinely study interest-driven subjects in a way that leverages one's lived experiences and identity is a privilege most often reserved for the wealthy (e.g. Gutiérrez et al., 2009; Walford, 2012; Willis, 1977). Responsive to this reality, LUL aims to serve those students who, because of financial or familial reasons, cannot afford to participate in the types of learning experiences often provided through private schooling or after-school programming. Funding for LUL originally started with a personal gift from one of its founders, as well as additional private gifts from its founders' social networks. At the time of the writing of this article, the program is still in operation, but its funding structure is in transition and LUL now relies upon an array of private and grant-funded resources.

To recruit students into the program, LUL youth workers seek guidance from the partner schools' guidance counselors. Guidance counselors are asked to identify and invite students from within their advisory groups who meet the LUL requirements and who they believe are struggling to remain engaged in their traditional school classes. LUL requirements are that students (a) are categorized in the Scottish Index of Multiple Deprivation categories 1-4 (akin to free and reduced-price lunch in the United States) and (b) that they agree to meet with their LUL youth worker (called "mentor" in practice) on a weekly basis.

In the school year 2015-2016 in which I conducted my case study, 10 students participated full time in LUL at Lochside High School. Since this time until the writing of this paper, the program has doubled its number of students and expanded to a second school site. During my field work, each student met weekly for 1 hour with their LUL youth worker in an available open study room in the school. Cam and Eddie ${ }^{1}$, the program's founders, were the only two youth workers during the time in which I carried out my fieldwork. Since then, the program has grown and they have hired multiple youth workers, a program operations manager, and a pedagogical support staff person.

\section{Researcher Role}

Since its inception in early 2015, I played a variety of roles for LUL. These roles included education research thought partner, volunteer youth mentor, and observant participant (described in detail below). My introduction to the program resulted from my decade-long friendship with Eddie-whom I met while doing my master's degree in England in 2009-2010. Eddie knew of my interests in equity, pedagogy, and youth development; therefore, after

\footnotetext{
${ }^{1}$ All youth worker and student names have been given pseudonyms.
} 


\section{Insights From a Scottish Youth Program}

developing the model for LUL, he reached out to me and asked for my perspectives. Eventually, my role as thought partner set the stage for our formal entrance into a research study, which gained Institutional Review Board/Ethical Research approval from both my United States-based institution and Lochside school.

\section{Methods}

The following research questions guided this study:

- What is the social organization of activity in Light Up Learning sessions?

- What are the behavioral and linguistic dimensions of Light Up Learning pedagogy? Relatedly, how do young people experience LUL pedagogy?

To answer these questions, I relied on multiple sources of data and a particular approach to inquiry that was informed by my training as a learning scientist grounded in the sociocultural tradition. The sociocultural tradition of research on learning and development is informed principally by the work of Lev Vygotsky, a Russian psychologist who argued that learning is fundamentally a social and cultural phenomenon. From a sociocultural perspective, learning is evidenced by transforming or shifting participation in meaningful activity (Rogoff, 1990), and best supported through the co-construction of a zone of proximal development, in which learning (with the help of more experienced others and culturally mediated tools) leads developmental processes (Vygotsky, 1934/1978). Putting this theory into methodological practice meant that I approached my investigation by focusing on the social organization of activity in LUL sessions.

More broadly, my approach to data collection and analysis was informed by a community-based approach to research (Strand et al., 2003) which involved keeping a researcher journal to document the development of my own feelings about the research alongside my participation. It also included engaging in weekly participant checks with the LUL youth workers in which they had the opportunity to comment on my sense-making of their interactions with the youth, including providing feedback on my fieldnotes and memos (Vossoughi \& Gutiérrez, 2014). The participant checks included sending my fieldnotes and analytical memos directly to the LUL youth workers and asking for their verbal and/or written feedback. While the analysis of findings is my own, the youth workers' feedback on my sense-making undoubtedly shaped my emergent understanding of the context in which I was studying, which was central to helping 


\section{Insights From a Scottish Youth Program}

me "manage bias" (Kirshner et al., 2011) as an observant and respectful, albeit outside participant in a new cultural context.

The data I draw upon are the result of 4 months of intensive fieldwork between December 2015 and March 2016 in which I was an observant participant. I use the term "observant participant" purposefully because while I did employ ethnographic research principles of jottings, careful observation, and subsequent descriptive fieldnotes (Spradley, 1979), I was a very active participant in the routine activities of LUL sessions and events throughout the duration of intensive fieldwork (Erickson, 1986). I observed 21 sessions, each of which was audio recorded. At the first parent meeting of LUL's Winter term in January 2016, I explained my proposed study to both students and parents. At that time, they were given the opportunity to consent and assent to be a part of the study, to which all of them willingly agreed. Toward the end of the fieldwork (March 2016), I interviewed 10 students, two school guidance counselors and one school administrator about their experiences with LUL, again employing an ethnographic, semistructured approach to interviews (Spradley, 1979). In addition, I fully immersed myself in all of the programmatic goings-on of LUL, including attending internal weekly meetings in which the youth workers reflected upon pedagogical strategies, as well as any corollary events such as meetings with school administrators, parent nights, and events related to potential funding opportunities.

After data collection was complete, I moved fluidly between inductively and deductively coding the data, a process that included the development of a broad descriptive coding scheme that attributed a "class of phenomena to a segment of text" in relation to my research questions (Miles \& Huberman, 1994, p. 57). This phase was followed up by a deductive approach that included reducing and categorizing excerpts into patterns that reflected my interest in the social organization of the teaching and learning activity within LUL, and in particular how adult-youth interactions shaped activity. For instance, because I was broadly interested in documenting the social organization of the adult-youth interaction and its impacts on learning and development, my inductive codes first included codes like "adult talk" and "student questions" and "adult directive/questions" and then became more precise such as "adult acknowledgement of youth strength or interest," "adult alignment with youth," and "adult attempts to transfer power in activity to youth."

Through multiple passes of reading, reviewing, and coding within and across each data source, I applied codes alongside engaging in a critical review of the youth studies and youth work 


\section{Insights From a Scottish Youth Program}

literature. In so doing, I created a third coding scheme, which reflected an attempt to characterize perceptions of LUL's unique positioning as an informal, albeit school-based youth program situated within a working-class community. Application and analysis of these tertiary codes across the data allowed me to move fluidly between a micro- and macro-level of analysis, in which I could attend to both the social organization of teaching and learning activities within the LUL sessions, as well as how the social contexts that surrounded these activities and relations were inflected within them.

\section{Analysis of Findings}

No two LUL sessions were the same, as individual curiosities and interest-related pursuits varied widely across the students. For example, Cory, who hopes to be a paramedic when he gets older, liked to explore the topics of emergency medicine, football, and the paranormal during his weekly sessions with his mentor. Grant, nearly graduated, often read excerpts of science fiction novels with his mentor, as they tried to make sense of complex plots and circuitous writing structures. Tom, a young rugby enthusiast, had recently discovered sports psychology, and liked to investigate the lives and careers of famous national players. Finally, Jane, an aspiring "boss," enjoyed having the opportunity to engage in political discussions about the possible future autonomous state of their country.

The activities of LUL sessions also took different forms and were pursued through a variety of digitally supported pedagogical strategies. Often, the students used their mobile devices to look up information, while the mentors used school-provided iPads. Other times, both student and mentor shared a desktop computer at the library or in one of the study rooms. Sometimes students communicated what they found in the moment to their mentor, or sometimes they took notes and brought them back, on paper or through email, for discussion toward the end of the session. By and large, students expressed an interest early on, and this interest guided the activity of the adult-youth pair for a number of weeks. Other times, students' interests faded, and they told their mentor that they were bored, uninterested, and/or wanted to explore something else, at which point the direction of their joint activity shifted.

Despite the rich and varied texture of the youth-led interest pursuits, as well as the distinct youth-adult relations that shaped each pursuit, analysis revealed certain linguistic and behavioral patterns that characterized both the organization of teaching and learning activity and the adult pedagogy of an LUL session. In what follows, I present findings according to the primary categories of support for youth development that emerged from my analysis, which 


\section{Insights From a Scottish Youth Program}

include the foregrounding of youth interests and the sharing of power between adults and young people in teaching and learning activity. After a discussion of these findings, I close by offering recommendations for practice.

\section{Foregrounding Youth Interests}

What emerged through careful analysis of interactions was not only the frequency with which the adult mentors named the importance of youths' interest, but also the multiple strategies and junctures at which they worked to ensure that it was those very interests that were driving the interactional work of the adult-youth pair. Indeed, the code of "adult naming youth interest" or "adult following youth interest" occurred 43 times across 21 session fieldnotes. The following two excerpts from fieldnote data are illustrative of how the adults worked in the moment to frame the youths' interest as the central driver of activity within their interactions. The first comes from a session with Cam and Luke, a 15-year-old student who had expressed interest in the topic of human anatomy. By checking his understanding in the moment and out loud (boldface in fieldnote below), of Luke's interest in listening to the audio recording on anatomy, Cam reaffirmed Luke as the person to set the direction of activity.

Cam asked Luke if it might be okay if that day, we all listened to radio show from BBC Channel 4 about anatomy, called "In our Time." Cam placed the iPhone in the middle of the table that the three of us were seated around. Before Cam started the recording, he looked at Luke and said, "let us know if you think this is boring and we will stop it, because we don't want to waste time here." (Fieldnote, January 2016)

In addition, Cam's comment about not "wasting time" points not to a need for the activity itself to produce some end or to reach completion by a certain stage, but rather to Cam's insistence on their interactions being centered around the interests of the young person. The mediating digital tool-in this case, the iPhone-was purposefully placed by Cam at the center of the table

around which he, Luke, and I sat, and served to enable a joint listening session and subsequent discussion of Luke's interests.

Similarly, when Eddie and Tom (youth) were reviewing Tom's recent work on an essay about rugby, Eddie took care to continually ask him about the direction he wanted to go in pursuit of his interest: 


\section{Insights From a Scottish Youth Program}

Tom asked if Eddie had seen Manchester United play last night. Eddie had, and so they talked about game highlights for about 2 minutes. Eddie then asked, "so where do you think you want to go from here with this Tom?" and turned the iPad (where the text of the essay was located) to Tom. Tom proposed to write about the upcoming match with Sam Burgess, a Scottish rugby star, and they got into a small conversation about a recent play he had made. Eddie said that Tom's plan sounded like a good idea, and that we [Eddie and I] would leave him alone for 10 minutes so that he could get started on that section of writing in peace. (Fieldnote, February 2016)

Throughout their time together, Tom openly and frequently expressed his interest in rugby, and his sessions with Eddie had prompted him to consider a future career in sports journalism or sports psychology. Yet as is illustrated through the above interaction, Eddie continually asked him questions about the direction he wanted to take in the activity at hand- positioning him, with the help of the iPad, as the person in the space whose interests would guide their next steps together.

Working to privilege youth interest in practice led to what might be considered "a snail's pace" of progress by those looking in from the outside. In fact, over the duration of intensive fieldwork, not one of the 10 students with whom Cam or Eddie worked finished a piece of work (e.g., an essay, a revision, an article or blog). For instance, Eddie and Dan (a 17-year-old male student), worked nearly two semesters on one essay about the Pittsburgh Steelers American football team. This was, in part, due to the purposeful check-in's that the youth workers had with the youth at the beginning of every session, to gauge the status of the their interest in their interest-pursuit-in other words, were they still genuinely curious about the topic/subject matter, or had their interests lessened or shifted? This routine pedagogical move, perhaps seemingly tedious, indexed not only the material and social reality of contemporary youth interests (DiGiacomo et al., 2018), but centered, in situ, the young people's everyday practicelinked and multiply constituted identities and perspectives (Nasir \& Hand, 2008; Wortham, 2006).

\section{Sharing Power: Honoring Youth Expertise in Learning Activity}

In addition to their interests, the LUL youth workers continually privileged the expertise of the youth at all stages of activity. Analysis of fieldnote data revealed routine instances of the youth workers deferring to the youth when engaged in discussions, which was captured most strongly 


\section{Insights From a Scottish Youth Program}

through the frequently occurring code of "adult asking youth for more information, to name structure, or to explain further" ( $N=45$ across 21 fieldnotes). Consider the following illustrative excerpt taken from the previously mentioned interaction between Cam and Luke around the topic of anatomy. Note, in particular, how Cam purposefully positioned Luke as an expert (boldface).

I (Author) asked to pause the audio recording because I said that it would help if I had a picture of what a nerve looked like in my head. This pause ensued into a nearly 30-minute discussion, led by Luke, prompted by questions from me and back-and-forth dialogue between Cam and Luke. When Luke didn't know about something, like how to draw the third type of nerve, he got out his notebook from his backpack and looked through the pages for it. He turned it to us so we could see and continued to explain. When Cam suggested an explanation for something, however, he would turn to Luke and say, "Luke, correct me if I'm wrong here . . . " When I asked a follow up question to them about sensory nerves ("so do we have more sensory nerves, then, in the areas of our body that we think of as sensitive?") both Cam and Luke agreed, and then I gave an example of placing your hand on something hot and not removing it. Luke smiled and said it's a bit more complicated, but that maybe if you have a mental health issue, your brain . . . at this moment Cam stopped him and asked if he might take it a bit slower to explain to me the exact process that flowed between me putting my hand on something hot and my brain telling my muscles to pull me away from it. Luke did this, often getting his notes out or drawing pictures on the piece of paper in front of him (Fieldnote, February 2016).

By saying out loud that Luke had the ability to correct him, as the adult, in his explanation, Cam lifted up Luke's expertise as valuable to the learning activity. And by asking him to slow down in his explanation to really help another adult's understanding, Cam again worked to position Luke-even within the short interaction-as someone with expert knowledge that could support another's genuinely emergent understanding. Importantly, Luke's sense-making was never constrained by a particular timetable or measurable outcome.

This pedagogic move by the adults of privileging the content-area expertise of the youth, naming that they themselves didn't necessarily know the answer, or that it was something that they would need to work more on together in order to figure out, emerged through a 


\section{Insights From a Scottish Youth Program}

pedagogically focused analysis of the social organization of activity within LUL sessions. Such instances were captured by codes of "sharing power" and "purposeful language," both used to characterize the following illustrative interaction, again between Cam and Luke on the topic of anatomy. In this interaction, Cam honored the expertise of the Luke not only by positioning him as an expert, but by pushing against the assumption that the adult in the space was the person who held all the knowledge or knew all the answers (boldface):

Luke paused the audio recording to ask a question to Cam about if, when the radio people talked about the fluid in the head, they were talking about the lymphatic system of the body. Cam said, "Well, the answer is that I don't know," and that "we'll have to look that up and find out." (Fieldnote, January 2016)

Employing these types of discursive moves (such as continual use of the "we" pronoun with inquiry-stance language, such as "find that out"), the youth workers pushed against normative notions of adult-as-expert in learning activity. Of note, available digital tools, such as hand-held smart devices or desktop computers, shaped the subsequent activities of "finding out" or "looking up" by serving as supports of and for the youth-led inquiry, when placed in the hands of the youth rather than in the hands of the adult.

Through analysis of youth interviews, too, it became clear that the youth experienced the relationship as one that supported their developing expertise. Nearly all (eight out of 10 ) youth reported that their LUL mentor treated them "like an adult" in response to the interview question of "How does your LUL mentor treat you during the sessions?" Consider, for example, Grant's illustrative response in which he not only expressed a felt sense of equity, but articulated feeling like an "expert":

He treats you just like anybody, like equally, he doesn't look down on you, he'l actually like to hear about what, and you get that feeling that he really wants to know about what you know, like I'm the expert for a small bit. (Interview with Grant, March 2016)

To have expertise and to be able to use expertise are two different things, especially for young people in school-based settings laden with historical and institutional norms for who holds the power (Kafai et al., 2008). Grant's response simultaneously reflects an understanding of his 


\section{Insights From a Scottish Youth Program}

relationship with Cam as equitable ("like anybody") and notably, as distinct from others in his social world of schooling ("for a small bit").

\section{Sharing Power: Making Space for Youth's Ideas Within School Hours}

Adults' naming space for a young person to contribute and experiencing space on the part of a young person are again, two different things. Analysis of youth interviews revealed a notable sense of youth's perception of freedom to explore within the adult-youth interactions over time, as well as a felt sense of encouragement from the adults, on the part of the youth, to delve into their curiosities in the moment. Consider the words of Trevor and Duke, in response to the following interview question: "In what ways are the LUL sessions different or similar to what you do in your regular school classes?" Note in particular the young people's use of "we" pronouns to describe the learning activity, and yet a simultaneous expression of room for development on the part of the youth themselves:

More freedom, like there is no set rules, like you need to do THIS in THIS amount of time (emphasis from Trevor). [In LUL] It's more like, here's what we're working on, I trust you, which is something I don't get in my other classes, and it's brilliant to just kind of have my own time but still learn at the same time. (Trevor)

In our regular classes we sit down and do bookwork and the teacher just talks to us. With Eddie we do lots of stuff, like we've been kneeling on the floor, putting bits everywhere, we do stuff on computers, reading books, getting active, just totally different. (Duke)

Both Trevor's and Duke's responses reflect a sense of the youth-adult relationship as more dialogic and equitable, and notably different than that which they experience in their classes. Across the 10 student interviews, all 10 students reported a marked sense of difference between LUL sessions and classroom-based learning, with regard to their opportunities for selfexpression, interest-related learning, and demonstration of competence. The following two youth responses are especially illustrative of a perceived difference in how learning happens within LUL in contrast to typical classrooms:

- " "[in LUL] I am learning in depth about new things that I never knew about before." (Trevor) 


\section{Insights From a Scottish Youth Program}

- "[in LUL] it's about learning successfully, instead of just being able to do [like in school], but like being able to understand how I'm doing and what I'm doing." (Zach)

Moreover, in response to the interview question that simply asked about what the young people did in LUL, youth responses reflected a felt sense of freedom that was distinct from typical school-based experiences. Grant, for example, said "it is a period once a week where you work on what you want and talk about what you want." Similarly, Amy said that she experiences "freedom to get to do what I want and learn what I want to learn." Indeed, across all the interviews, youth expressed some sense of freedom to think and to be themselves within their adult-youth relationships in particular, saying that whilst at LUL, they got to "talk freely about the things you like" (Jane), "look into stuff you're interested in" (Zach), "research what I want" (Trevor), and "discuss something I find interesting" (Duke). Across the interviews, then, there emerged a sense of genuine support for interest-related learning and learning with understanding (see Bransford et al., 1999) reported by the young people with regard to how they experienced the LUL environment. Of note, the youth often contrasted this type of learning and agency to that which they experienced in their routine classes in school.

Analysis of youth responses in regard to their relationship with their LUL mentor also suggest that the youth experienced the relationship itself as one with ample space for them to think, act, and be freely, as competent young persons in their own right-fundamental to what is known about how to support positive youth development (Eccles \& Gootman, 2002; Nakkula \& Toshalis, 2006). Consider the pattern of responses that emerged from the interviews, when I asked the youth to describe their relationship with their LUL mentor:

- Four youth said it was "like a friendship."

- Three called it "not formal" and "personal."

- Two called it "comfortable/relaxed."

Taken together, these responses suggest that LUL's approach did not adhere to the typically hierarchical and often efficiency-oriented patterns of adult-youth relations in teaching and learning activity. Instead, as their responses revealed, the young people experienced the relationship as one akin to that of a friendship-with a perceived sense of more agency than is typical between youth and adults in educational spaces. 


\section{Insights From a Scottish Youth Program}

\section{Limitations of Sharing Power}

Analysis of interview and fieldnote data suggests that the organization of LUL activity and LUL pedagogy encouraged a sharing of power between adult mentor and young person. At the same time, it is important to remember the ubiquitous and all-pervasive nature of power itself. As articulated by Chávez and Soep (2005):

The mutual engagement, investment, and vulnerability between young people and adults that underpin collegial pedagogy never cancel out, nor should they obscure, the very real institutional, historical, and cultural forces through which power circulates in any collegial relationship and any pedagogical relationship. (p. 420)

In the case of LUL, the mentors (Cam and Eddie) during the time of this study identified as middle- and upper-class, Cambridge-educated White cisgender males. The young people (all of whom identified as white and cisgender) in contrast, were from markedly different socioeconomic backgrounds. Through informal conversations with the young people, some of them told me that they knew that Cam and Eddie were not from their neighborhoods because of the way they talked. Some of them also asked me questions about what it was like to go to Cambridge University (with Cam and Eddie), indicating an awareness of the power along institutional lines that their mentors carried. In line with a Chávez \& Soep (2005) perspective, then, I do not purport that the sharing of power in LUL activity transcended or cancelled out the "very real institutional, historical, and cultural forces through which power circulates in any collegial or pedagogical relationship."

\section{Discussion}

Analysis of data suggests that LUL sessions created an environment that was not only supportive of youth learning, but supportive of "interest-driven" or "interest-related learning" (Azevedo, 2011; 2013; Barron, 2006). The primary activity of the sessions was the joint investigation of students' life-wide interest(s), an activity which was facilitated by LUL youth workers supporting the young person's learning by engaging in meaningful and explicitly dialogic discussions of their interest(s), joining them in exploring about their interest(s), and accessing additional resources to complement their exploration of that/those interest(s). In sum, analysis of the social organization of activity revealed that LUL sessions supported youth development by creating an environment in which young people felt encouraged to engage in 


\section{Insights From a Scottish Youth Program}

interest-related learning pursuits that mattered to them through a supportive relationship with consistent adult guidance (recall tenets of PYD from Eccles \& Gootman, 2002).

In addition, analysis of the behavioral and linguistic dimensions of LUL pedagogy, which included youth workers continually working to position (verbally, spatially, and with the use of available technological or material tools) the young people's interest and expertise as valuable to joint activity, suggested that the young people experienced LUL as a space in which they could demonstrate their competence with someone who valued their expertise. In naming their relationship with their LUL mentor as "like a friendship/not normal" and expressing a sense of "freedom" to explore their interests, young people's voices serve as evidence that the LUL pedagogy was successful, at least in part, in disrupting typical power-dynamics between adults and youth in teaching and learning settings (see Kafai et al., 2008). As youth development scholars Nakkula and Toshalis (2006) have argued, learning and relational development are deeply intertwined: "like anyone else, youth want to be engaged as thinking, feeling, valued members of a community in which they are understood as stakeholders" (p. 81). In the case of LUL, the purposeful sharing of power within the youth-adult relationship was critical to the encouragement of interest-driven learning in a way that was simultaneously supportive of youth development.

Key differences between LUL and classrooms make one cautious, however, to generalize findings to the school context. Unlike school, for example, LUL sessions were one-on-one and youth self-selected into LUL (that is, after their guidance counselor invited them). Both of these aspects of its functioning are markedly different from the pressures and dynamics of a typical classroom. Undoubtedly, the relational dynamic differences (from one-to-one to one-to-thirty) and the fact that the young people are required (rather than invited) to go to class mediate what is possible in the design and organization of learning activity and adult-youth relations. In addition, when the youth attended LUL sessions, they missed an hour of regular instructionthe academic consequences and potential social/peer stigma remain unknown to the present analysis.

Despite these key structural differences, however, there are still lessons to be learned for how to design interest-related learning and promote youth development in school-based settings. As Nasir (2008) has often articulated in her studies of informal learning, "while it is naïve to think that out-of-school learning environments can be imported into school settings wholesale," there are important lessons we can learn from how such alternative environments "simultaneously 


\section{Insights From a Scottish Youth Program}

support the social, emotional, and cognitive needs of learners" (2008, p. 532)-and the present analysis was pursued in a similar spirit. This analysis in particular suggests that teachers might do well to (a) consider how to incorporate more time and space for students to pursue their interests and curiosities, even within routine lessons and disciplinary content learning, and (b) consider how to create classroom-based activities or discussions that allow students to assume more expert roles where they can freely and fluidly demonstrate their competence and expertise.

\section{Limitations}

There are a number of limitations to this study. The first is related to the primary construct under examination itself: youth interest. Because interest itself is well-documented to be a multi-dimensional, multi-contextual, and dynamic phenomenon (Azevedo, 2011, 2013; DiGiacomo et al., 2018), a more robust methodological toolkit would include the addition of longitudinal and cross-contextual components-which funding constraints did not allow. Additional studies would do well to follow the LUL youth over time, after they have left the program and moved into the many spaces in which they live and learn, to examine if and how they continued to pursue their interests. Second, because LUL as a program was comprised of students who agreed to participate after an invitation from their guidance counselor, the sample for this investigation was not necessarily representative of this (or other) school's population(s). Accordingly, findings should not be generalized outside of this particular context.

Lastly, this study attempted to attend to issues of relational power dynamics between youth worker and young person in the context of interest-related learning activity. In so doing, it is important to name my own positionality as a White-skinned, Latinx, middle class adult woman (and therefore member of a number of dominant and nondominant communities), as well as a long-time friend of the adult youth workers-and to own the ways that this positionality shapes my perspective and analysis. Potential implications include an overestimation of the extent to which power was shared between youth worker and young person, given that I do not have the lived experience of occupying a marked social position in a society with deep and historically situated class hierarchies and divisions. While this limitation of the analysis can never be overcome, I have attempted to address it through continual data-related member checks with the involved adults as well as the purposeful collection of first-person perspectives from the youth in the form of interviews and informal conversations throughout the fieldwork. 


\section{Insights From a Scottish Youth Program}

\section{Recommendations for Practice}

The notion of foregrounding youths' interest and expertise, and the sharing of power in the design of activity is not new for the field of learning and youth development. However, this should not mean that continued investigation and discussion around the constitutive features of this type of relational pedagogy is not worthwhile, given the ubiquity of more instrumentally oriented conceptualizations and enactments of learning in contemporary informal and formal education settings. Accordingly, I offer the following recommendations for practice that emerged from both analysis of activity within LUL sessions and feedback from LUL youth workers. These recommendations are offered in the spirit of informing the pedagogic organization of designed learning environments that aim to genuinely support students' developing interests and expertise:

- Consider the positioning of the primary technological or material tool (e.g. iPad, white board marker, book, computer) through which the youth are pursuing their interest(s). Ask yourself, toward whom is this tool oriented? And for what purposes, and for whom, was this tool designed? Think about physically repositioning the tool toward or in the hands of the youth.

- Consider the time frame and/or deadline that has been set for the particular activity. Ask yourself: to whose timeline are you ascribing? Genuine pursuit of interest(s) takes time and varies in its texture and shape. Try to become comfortable with social silences, pauses, and interruptions-so often silenced in the pursuit of a deadline-and yet integral to our sense-making capabilities as human beings.

- Resist the urge to need to produce something. Contemporary times have conditioned us to value product-over-process (see critique by Blum-Ross \& Livingstone, 2016), but consider the possibility of non-completion. Ask yourself, for whom and/or for what purpose am I encouraging an end product?

- Be curious. Engage in meaningful ways with the young person(s), as if you would your friend's younger sibling. In other words, don't feign interest or engagement, but rather work to find an aspect of the young person's interest that is interesting to you, making visible and folding in aspects of both joint interest/disinterest and agreement/disagreement. 


\section{Insights From a Scottish Youth Program}

\section{Conclusion}

In this $3^{\text {rd }}$ decade of the $21^{\text {st }}$ century, schools and youth programs have come under heightened pressure to produce individually oriented and measurable outcomes for their young people. The empirical case of LUL serves as an instance of a youth program whose pedagogical approach was guided, at the broadest level, by a purposeful attempt on the part of the adult youth workers to encourage learning within the four walls of a traditional schoolhouse and during school hours that wasn't explicitly tied to exam performance or character correction. Such an attempt is not inconsequential for a contemporary youth program in a working-class community. Analysis of the social organization of activity within LUL revealed the ways in which purposeful pedagogic moves enabled young people to feel that learning about what mattered to them mattered and was a worthwhile pursuit in and of itself.

For those whose research and/or practice focuses on youth development, the importance of healthy and supportive youth-adult relationships is not new. Yet as Pekel's (2019) recent thought leader commentary suggested, we need to consider how to "move beyond" our awareness that "relationships matter" by examining how to build the type of developmental relationships known to be consequential for . . . youth learning and development. This call to action is especially important when one considers that these types of relationships remain the exception, rather than the expectation for teacher-student relations in schools-where young people spend most of their time. The form and function of LUL, with its emphasis on interestdriven learning through a purposefully dialogic and less hierarchical youth-adult relationship, serve as an example of how educators might bring together insights from what is known about how people learn best with what is known about how to support positive youth development.

\section{References}

Allen, C., DiGiacomo, D., Van Horne, K., \& Penuel, W.R. (2018). Pursuing interests and getting involved: Exploring the conditions of sponsorship in youth learning. Digital Education Review, 33, 120-129. https://files.eric.ed.gov/fulltext/EJ1183653.pdf

Azevedo, F. S. (2011). Lines of practice: A practice-centered theory of interest relationships. Cognition and Instruction, 29(2), 147-184.

Azevedo, F. S. (2013). The tailored practice of hobbies and its implication for the design Of interestdriven learning environments. Journal of the Learning Sciences, 22(3), 462-510. https://doi.org/10.1080/10508406.2012.730082 
Journal of Youth Development | http://jyd.pitt.edu/ | Vol. 15 Issue 5 DOI 10.5195/jyd.2020.869

Insights From a Scottish Youth Program

Baldridge, B. J. (2019). Reclaiming community: Race and the uncertain future of youth work. Stanford University Press.

Barron, B. (2006). Interest and self-sustained learning as catalysts of development: A learning ecology perspective. Human Development, 49(4), 193-224. https://doi.org/10.1159/000094368

Barron, B. (2010). Conceptualizing and tracing learning pathways over time and setting. Yearbook of the National Society for the Study of Education, 109(1), 113-127.

Blum-Ross, A., \& Livingstone, S. (2016). From youth voice to young entrepreneurs: The individualization of digital media and learning. Journal of Digital and Media Literacy, 4(1-2), 1- 21.

Bransford, J., Brown, L., \& Cocking, R. (Eds.). (1999). How people learn: brain, mind, experience, and school. National Academy Press.

Brown, A. (1992). Design experiments: Theoretical and methodological challenges in creating complex interventions in classroom settings. The Journal of the Learning Sciences, 2(2), 141-178. https://doi.org/10.1207/s15327809jls0202 2

Chávez, V., \& Soep, E. (2005). Youth radio and the pedagogy of collegiality. Harvard Educational Review, $75(4), 409-434$.

Cole, M., \& Distributive Literacy Consortium. (2006). The Fifth Dimension: An after-school program built on diversity. Russell Sage Foundation.

DiGiacomo, D. \& Penuel, W. R. (2018). Organizing learning environments for relational equity with new digital media. In (Eds.) P. Resta \& T. Laferrière (Eds.), International handbook of information technology in primary and secondary education ( $2^{\text {nd }}$ ed.). Springer International. https://doi.org/10.1007/978-3-319-53803-7 75-1

DiGiacomo, D., Van Horne, K., Van Steenis, E., \& Penuel, W. R. (2018). The material and social constitution of interest. Learning, Culture \& Social Interaction, 19, 51-60. https://doi.org/10.1016/j.Icsi.2018.04.010

Eccles, J., \& Gootman, J. (2002). Community programs to promote youth development. National Academies Press.

Erickson, F. (1986). Qualitative methods in research on teaching. In M. C. Wittrock (Ed.), Handbook of research on teaching ( $3^{\text {rd }}$ ed., pp. 119-161). MacMillan.

Gee, J. P. (2007). Good video games+ good learning: Collected essays on video games, learning, and literacy. Peter Lang.

Gutiérrez, K. D., Morales, P. Z., \& Martinez, D. C. (2009). Re-mediating literacy: Culture, difference, and learning for students from nondominant communities. Review of Research in Education, 33(1), 212-245. https://doi.org/10.3102/0091732X08328267 
Halpern, R. (2002). A different kind of child development institution: The history of after-school programs for low-income children. Teachers College Record, 104(2), 178-211.

\section{https://doi.org/10.1111/1467-9620.00160}

Halpern, R. (2005). Instrumental relationships: A potential relational model for inner-city youth programs. Journal of Community Psychology, 33(1), 11-20. https://doi.org/10.1002/jcop.20032

Hamilton, L., \& Brown, J. (2005). 'Judgement day is coming!': young people and the examination process in Scotland. Improving Schools, 8(1), 47-57. https://doi.org/10.1177/1365480205049339

Hidi, S., \& Renninger, K. A. (2006). The four-phase model of interest development. Educational psychologist, 41(2), 111-127. https://doi.org/10.1207/s15326985ep4102 4

Honig, M., \& McDonald, M. (2005). From promise to participation: Afterschool programs through the lens of socio-cultural learning theory. Afterschool Matters Occasional Paper Series, 5, 1-26.

Ito, M., Arum, R., Conley, D., Guttiérez, K., Kirshner, B., Livingstone, S., Michalchik, V., Penuel, W., Peppler, K., Pinkard, N., Rhodes, J., Salen Tekinbaş, K., Schor, J., Sefton-Green, J., \& Watkins, S. C. (2020). The Connected Learning Research Network: Reflections of a decade of engaged scholarship. The Connected Learning Alliance.

Kafai, Y., Desai, S., Peppler, K., Chiu, G., \& Moya, J. (2008). Mentoring partnerships in a community technology centre: A constructionist approach for fostering equitable service learning. Mentoring \& Tutoring: Partnership in Learning, 16(2), 191-205.

\section{http://dx.doi.org/10.1080/13611260801916614}

Kirshner, B. (2015). Youth activism in an era of education inequality. NYU Press.

Kirshner, B., Pozzoboni, K., \& Jones, H. (2011). Learning how to manage bias: A case study of youth participatory action research. Applied Developmental Science, 15(3), 140-155. https://doi.org/10.1080/10888691.2011.587720

Kwon, S. A. (2013). Uncivil youth: Race, activism, and affirmative governmentality. Duke University Press. Larson, K., Ito, M., Brown, E., Hawkins, M., Pinkard, N. and Sebring, P. (2013). Safe space and shared interests: YOUmedia Chicago as a laboratory for connected learning. BookBaby.

Larson, R. (2000). Towards a psychology of positive youth development. American Psychologist, 55(1), 170-193. https://doi.org/10.1037/0003-066X.55.1.170

Lecusay, R. (2015). Building zones of proximal development with computer games in a UC Links afterschool program. International Journal for Research on Extended Education, 2(2). https://doi.org/10.3224/ijree.v2i2.19544

McLaughlin, M. (2000). Community counts: How youth organizations matter for youth development. Public Education Network.

Michalchik, V., \& Gallagher, L. (2010). Naturalizing assessment. Curator: The Museum Journal, 53(2), 209-219. https://doi.org/10.1111/j.2151-6952.2010.00020.x 
Journal of Youth Development | http://jyd.pitt.edu/ | Vol. 15 Issue 5 DOI 10.5195/jyd.2020.869

Insights From a Scottish Youth Program

Miles, M. B., \& Huberman, A. M. (1994). Qualitative data analysis: An expanded sourcebook. Sage.

Nakkula, M., \& Toshalis, E. (2006). Understanding youth: Adolescent development for educators. Harvard Education Press.

Nasir, N. S. (2008). Everyday Pedagogy: Lessons from basketball, track and dominoes. Phi Delta Kappan, 89(7), 529-532. https://doi.org/10.1177/003172170808900717

Nasir, N. S., \& Hand, V. (2008). From the court to the classroom: Opportunities for engagement, learning, and identity in basketball and classroom mathematics. The Journal of the Learning Sciences, 172), 143-179. https://doi.org/10.1080/10508400801986108

Patall, E., Cooper, H., \& Allen, A. (2010). Extending the school day or school year: A systematic review of research (1985-2009). Review of Educational Research, 80(3), 401-436. https://doi.org/10.3102/0034654310377086

Pekel, K. (2019). Moving beyond relationships matter: An overview of one organization's work in progress. Journal of Youth Development, 14(4), 1-13. https://doi.org/10.5195/jyd.2019.909

Penuel, W. R., DiGiacomo, D., Van Horne, K., \& Kirshner, B. (2016). A social practice theory of learning and becoming across contexts and time. Frontline Learning Research, 4(4), pp. 30-38. http://dx.doi.org/10.14786/flr.v4i4.205

Pinkard, N., Erete, S., Martin, C., \& McKinney de Royston, M. (2017). Digital youth divas: Exploring narrative-driven curriculum to spark middle school girls' interest in computational activities. Journal of the Learning Sciences, 26(3), 477-516. https://doi.org/10.1080/10508406.2017.1307199

Rocha, E. (2006, February 13). More than just moments in time. Center for American Progress. https://www.americanprogress.org/issues/education-k-12/news/2006/02/13/1843/more-thanjust-moments-in-time/

Rogoff, B. (1990). Apprenticeship in thinking: Cognitive development in social context. Oxford University Press.

Scottish Executive. (2013). Determined to succeed: A review of enterprise in education. http://hdl.voced.edu.au/10707/111208

Sefton-Green, J. (2012). Learning at not-school: A review of study, theory, and advocacy for e education in non-formal settings. MIT Press.

Spradley, James P. (1979). The ethnographic interview. Holt, Rinehart, and Winston.

Stevens, R., Jona, K., Penney, L., Champion, D., Ramey, K. E., Hilppö, J., Echevarria, R. and Penuel, W. (2016, June). FUSE: An alternative infrastructure for empowering learners in schools. Paper presented at the International Conference of the Learning Sciences, Singapore.

Strand, K. J., Cutforth, N., Stoecker, R., Marullo, S., \& Donohue, P. (2003). Community-based research and higher education: Principles and practices. John Wiley \& Sons. 
Journal of Youth Development | http://jyd.pitt.edu/ | Vol. 15 Issue 5 DOI 10.5195/jyd.2020.869 Insights From a Scottish Youth Program

Vossoughi, S., \& Gutiérrez, K. (2014). Studying movement, hybridity, and change: Toward a multi-sited sensibility for research on learning across contexts and borders. Teachers College Record, $116(14), 603-632$.

Vygotsky, L. (1934/1978). Mind in society. Cambridge: Harvard University Press.

Walford, G. (2012). Privatization and privilege in education. Routledge.

Walkington, C., \& Bernacki, M. L. (2014). Motivating students by "personalizing" learning around individual interests: A consideration of theory, design, and implementation issues. In S. Karabenick \& T. C. Urban (Eds.), Interventions (Advances in Motivation and Achievement, Vol. 18), 139-176. Emerald Group. https://doi.org/10.1108/S0749-742320140000018004

Watson, C. (2010). Educational policy in Scotland: inclusion and the control society. Discourse: studies in the cultural politics of education, 31(1), 93-104. https://doi.org/10.1080/01596300903465443

Willis, P. (1977) Learning to labor: How working class kids get working class jobs. Columbia University Press.

Wortham, S. (2006). Learning identity: The joint emergence of social identification and academic learning. Cambridge University Press.

Zeldin, S., Christens, B. D., \& Power, J. L. (2013). The psychology and practice of youth-adult partnership: bridging generations for youth development and community change. American Journal of Community Psychology, 51(3-4), 385-397. https://doi.org/10.1007/s10464-012-9558-y 